\title{
Izolované populace praménky Bythinella austriaca (Frauenfeld, 1857) (Gastropoda: Hydrobiidae) v okolí Prahy
}

\author{
Isolated populations of Bythinella austriaca (Frauenfeld, 1857) (Gastropoda: \\ Hydrobiidae) in Prague surroundings (Czech Republic)
}

\author{
LUBOŠ BERAN \\ Agentura ochrany přirody a krajiny ČR, Správa Chráněné krajinné oblasti Kokořínsko, Česká 149, CZ-27601 Mělník, \\ e-mail:lubos.beran@nature.cz
}

\begin{abstract}
Beran L., 2010: Izolované populace praménky Bythinella austriaca (Frauenfeld, 1857) (Gastropoda: Hydrobiidae) v okolí Prahy [Isolated populations of Bythinella austriaca (Frauenfeld, 1857) (Gastropoda: Hydrobiidae) in Prague surroundings (Czech Republic)]. - Malacologica Bohemoslovaca, 9: 5-10. Online serial at $<$ http://mollusca.sav.sk $>$ 11-March-2010.
\end{abstract}

\begin{abstract}
This paper completes the knowledge of an occurrence of Bythinella austriaca (Frauenfeld, 1857) (Gastropoda: Hydrobiidae) in surroundings of Prague - capital of the Czech Republic. However, this species is not rare in the eastern part of the Czech Republic, sites on north-western otskirts of Prague are isolated far from the main distribution area. Altogether, 63 sites potentially suitable for $B$. austriaca were investigated in this area, and occurrence of this species was confirmed in 11 of them. B. austriaca was found in springs, rivulets and small brooks, more numerous populations were found in springs. Historical occurrence data in this area were compared with results of research done in 2003, 2006 and 2010. Actual situation of this species in Prague surroundings is problematic and survival of some populations is not guaranteed.
\end{abstract}

Key words: Bythinella austriaca, Gastropoda, Hydrobiidae, Prague surroundings, distribution

\section{Úvod}

Praménka Bythinella austriaca (Frauenfeld, 1857) je jediným zástupcem rodu Bythinella $\mathrm{v}$ České republice, i když nelze vyloučit, že se v ČR vyskytuje více doposud neodlišovaných druhů (BERAN 2002). Rod Bythinella je s ohledem na kvartérní historii Evropy vázán především na jižněji položené oblasti a severněji proniklo pouze několik druhů. Bythinella austriaca je druhem s východoalpsko-karpatským rozšířením (GLÖER 2002) a jeho výskyt v ČR je vázán především na východní část, a to východní Čechy a Moravu (viz Obr. 1). Izolovaná oblast výskytu se nachází na severozápadním okraji Prahy na pravém břehu Vltavy a leží zároveň na severozápadním okraji areálu. Další dva neověřené údaje pocházejí z Vaňova u Ústí nad Labem (Petrbok 1938b, lgt. J. Wiesner, 4.5.1894) a Malých V̌šelis na Mladoboleslavsku (Mikvas 1963). Výskyt v Praze a okolí je znám z okolí Statenic (Petrbok 1938a), Středokluk (PетRвок 1939a), Tuchoměřic (Ретrвok 1939b) a z údolí Šáreckého a Nebušického potoka (LožEK 1945, 1953). Jediným nálezem z nedávné doby je výskyt v prameni u Spáleného mlýna v Tichém údolí (Hoffmann \& PoKORNÝ 1997). V Červeném seznamu ohrožených druhů České republiky je praménka hodnocena jako zranitelný druh (BERAN et al. 2005). Na základě těchto nedostatečných a až na jedinou výjimku velmi starých údajů byl proveden průzkum historických a jiných potenciálně vhodných lokalit na severozápadním okraji Prahy a okolí, jehož výsledky jsou předloženy v této práci.

\section{Metodika a materiál}

Historická data byla získána z autorovy databáze, která kromě autorových údajů obsahuje přepis dostupných publikovaných i nepublikovaných prací, údaje získané z kartoték a sbírek muzeí a od jiných malakologů. Údaje o současném rozšíření použité v této práci jsou získané vlastním terénním průzkumem autora v letech 2003, 2006 a 2010. Sběr byl na většině lokalit prováděn kombinací vizuální metody (prohlížením kamenů a jiných předmětů ve vodě) a odběrů $\mathrm{z}$ vegetace a sedimentu za pomoci kovového kuchyňského cedníku (průměr $20 \mathrm{~cm}$, velikost ok 0,5-1 mm). Zkoumány byly potenciálně vhodné lokality - prameniště, studánky, pramenné stružky, menší vodní toky a to tak, aby byl podchycen co největší počet potenciálně vhodných lokalit v celé zkoumané oblasti. Průzkum byl prováděn i v zimních měsících, kdy lze s úspěchem identifikovat vhodné lokality, které nejsou zamrzlé a jsou dobře viditelné zejména za sněhové pokrývky.

Materiál získaný při průzkumu byl ve většině případů určen na místě a vrácen na lokalitu. U druhů determinovatelných pouze pomocí lupy (většina druhů rodu Pisidium) byl materiál determinován až v laboratoři. Měkkýši byli determinováni pouze podle schránek. Systém a nomenklatura jsou převzaty z práce BERAN (2002) a upraveny podle aktuální verze přehledu měkkýšů ČR (JuŘIČKOvÁ et al. 2008). 


\section{Přehled zkoumaných lokalit}

V této části jsou uvedeny popisy jednotlivých lokalit. Údaje jsou řazeny následovně: číslo lokality, zeměpisné souřadnice (odečtené z digitální mapy dostupné na http:// www.mapy.cz/), kód pole pro faunistické mapování (BuCHAR 1982, Pruner \& Míka 1996), název nejbližší obce, lokalizace a popis lokality, datum průzkumu. Tučnou kurzívou jsou vyznačena čísla lokalit s výskytem praménky Bythinella austriaca.

1 - 5008'04"N, 14²1'03"E, 5851, Středokluky, vodní nádrž na prameni pod kostelem ve Středoklukách, 5.3.2006;

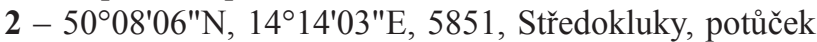
vytékající z vodní nádrže u kostela nad ústím do rybníčka, 5.3.2006; 3 - 50 $00^{\circ} 07^{\prime \prime} \mathrm{N}, 1^{\circ} 14^{\prime} 25^{\prime \prime} \mathrm{E}, 5851$, Středokluky, pramen v háji u Středokluk, 5.3.2006; 4 - 5008'21"N, $14^{\circ} 14^{\prime} 11^{\prime \prime E}, 5851$, Středokluky, Dolanský potok nad přemostěním dálnicí severně od Středokluk, 5.3.2006; 5 - 5008'19"N, 14¹4'15"E, 5851, Středokluky, kanál před ústím do Dolanského potoka nad přemostěním dálnicí severně od Středokluk, 5.3.2006; 6 - 5008'32"N, 14¹9'12"E, 5851, Středokluky, drobný kanálek pod lesem na pravém břehu Dolanského potoka nad Kalingrovým mlýnem, 5.3.2006; 7 - 5008'39"N, 14¹4'16"E, 5851, Stř̌edokluky, pramen a pramenná stružka na pravém břehu Dolanského potoka severně od Kalingrova mlýna, 5.3.2006; 8 - 5009'13"N, 14²15'06"E, 5851, Malé Číčovice, studánka u potůčku na jihovýchodním okraji Malých Č́ícovic, 5.3.2006; 9 - 5009'13"N, 14¹5'07"E, 5851, Malé Č́ičovice, potůček na jihovýchodním okraji Malých Ćíčovic, 5.3.2006; 10 - 5008'59"N, 14²15'33"E, 5851, Malé Číčovice, potůček v půli cesty mezi Malými Č́íčovicemi a Pazdernou, 5.3.2006; 11 - 5008'43"N, 14¹5'47"E, 5851, Pazderna, prameniště v lesíku severovýchodně od Pazderny, 5.3.2006; 12 - 5008'37"N, 14ํำ'41"E, 5851,
Pazderna, potůček pod rybníčkem v Pazderně, 5.3.2006; 13 - 5008'35"N, 14²15'42"E, 5851, Pazderna, tři studánky nad rybníčkem v Pazderně, 5.3.2006; 14 - 50¹0'18"N, $14^{\circ} 20^{\prime} 52 " \mathrm{E}, 5852$, Úholičky, pravostranný přítok potoka tekoucího od Velkých Př́lep do Vltavy v lesním údolí u Podmoráně, 8.1.2006; 15 - 50¹0'09"N, 14²0'50"E, 5852, Úholičky, potok tekoucí od Velkých Př́lep v Podmoráni asi $200 \mathrm{~m}$ před ústím do Vltavy, 8.1.2006; 16 - 5007'53"N, 1416'29"E, 5851, Tuchoměřice, pramen a pramenná stružka v sadu na levém břehu Únětického potoka na severozápadním okraji Tuchoměřic, 4.3.2006; $17-50^{\circ} 07^{\prime} 41^{\prime \prime N}, 14^{\circ} 16^{\prime} 25^{\prime \prime E}, 5851$, Tuchoměřice, Únětický potok na jihozápadním okraji Tuchoměřic, 4.3.2006; 18 - 5006'56"N, 14ำ17'23"E, 5851, Přední Kopanina, potůček na jihozápadním okraji Přední Kopaniny, 4.3.2006; 19 - 5007'31"N, 14ำ18'08"E, 5851, Přední Kopanina, studánka Pod Juliánkou severovýchodně od Přední Kopaniny u potoka, 4.3.2006; $20-50^{\circ} 07^{\prime} 29^{\prime \prime} \mathrm{N}, 1^{\circ} 18^{\prime} 11^{\prime \prime E}, 5851$, Přední Kopanina, potok nad studánkou Pod Juliánkou tekoucí od Přední Kopaniny ke Statenicím, 4.3.2006; 21 - 5007'43"N, 14²18'18"E, 5851, Přední Kopanina, potok tekoucí z Přední Kopaniny ke Statenicím v půli cesty mezi Přední Kopaninou a ústím do Únětického potoka u Štěrbova mlýna, 4.3.2006; 22 - 5007'54"N, 14¹8'16"E, 5851, Tuchoměřice, potok tekoucí od Přední Kopaniny ke Štěrbovu mlýnu asi $400 \mathrm{~m}$ od jeho ústí do Únětického potoka, 5.3.2006; $23-50^{\circ} 08^{\prime} 06^{\prime \prime} \mathrm{N}, 1^{\circ} 18^{\prime} 14^{\prime \prime} \mathrm{E}, 5851$, Tuchoměřice, levostranná stružka před ústím do Únětického potoka pod Štěrbovým mlýnem jihozápadně od Statenic, 8.1.2006; $24-50^{\circ} 08^{\prime} 07^{\prime \prime} \mathrm{N}, 1^{\circ} 18^{\prime} 36^{\prime \prime E}, 5851$, Statenice, dvě prameniště na pravém břehu Únětického potoka mezi Štěrbovým a Kopaninským mlýnem, 8.1.2006; $25-50^{\circ} 08^{\prime} 25^{\prime \prime} \mathrm{N}, 14^{\circ} 18^{\prime} 47^{\prime \prime} \mathrm{E}, 5851$, Statenice, prameniště (studna a stružka) v zahradě v nivě Únětického potoka na

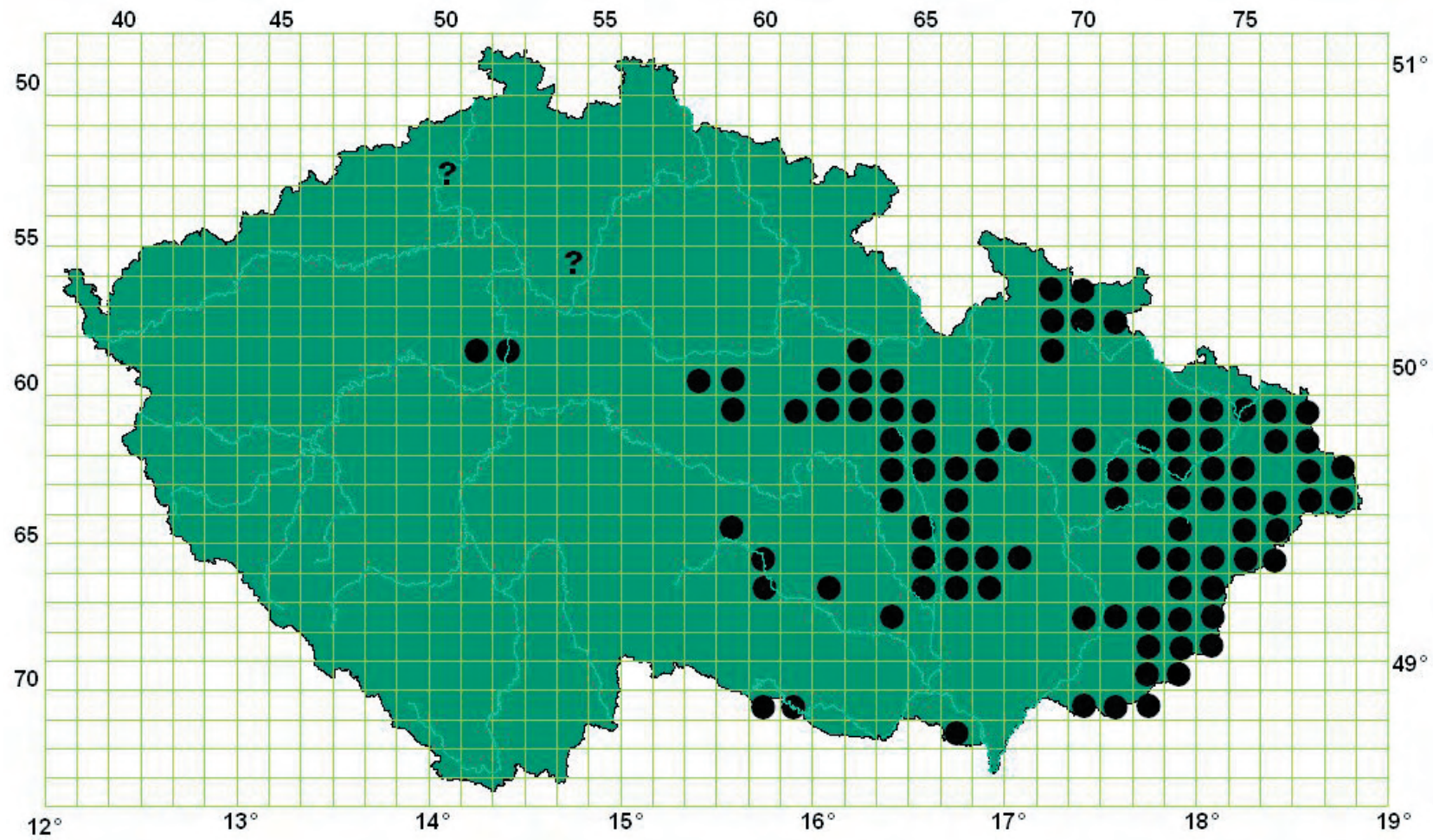

Obr. 1. Rozšíření praménky Bythinella austriaca v České republice (podle Beran 2002, doplněno).

Fig. 1. Distribution of Bythinella austriaca in the Czech Republic (according Beran 2002, completed). 
levém břehu na jihozápadním okraji Statenic, 8.1.2006; 26 - 5008'32"N, 1419'09"E, 5851, Statenice, Únětický potok ve Statenicích, 8.1.2006; $27-50^{\circ} 08^{\prime} 52^{\prime \prime N}$, $14^{\circ} 20^{\prime} 02^{\prime \prime E}, 5852$, Černý Vůl, Únětický potok v Černém Volu, 4.4.2003; 28 - 50 $08^{\circ} 48^{\prime \prime} \mathrm{N}, 1^{\circ} 21^{\prime} 43^{\prime \prime} \mathrm{E}, 5852$, Únětice, prameniště u potůčku tekoucího od Horoměřic asi $200 \mathrm{~m}$ před jeho ústím do Únětického potoka, 5.3.2006; $29-50^{\circ} 08^{\prime} 46^{\prime \prime} \mathrm{N}, 1^{\circ} 22^{\prime} 43^{\prime \prime E}, 5852$, Suchdol, drobné prameniště u bývalého Tůmova mlýna, 24.1.2010; $30-50^{\circ} 08^{\prime} 42^{\prime \prime} \mathrm{N}, 14^{\circ} 23^{\prime} 00^{\prime \prime} \mathrm{E}, 5852$, Suchdol, potůček tekoucí ze Suchdola u mostku silnice, 24.1.2010; $31-50^{\circ} 08^{\prime} 49^{\prime \prime} \mathrm{N}, 1^{\circ} 23^{\prime} 00^{\prime \prime} \mathrm{E}, 5852$, Suchdol, potůček tekoucí ze Suchdola před svým ústím do Únětického potoka, 5.3.2006; 32 - 5008'48"N, 14²2'57"E, 5852, Suchdol, drobné prameniště mezi ústím drobného př́toku a Únětickým potokem asi $100 \mathrm{~m}$ východně od Spáleného mlýna, 24.1.2010; $33-50^{\circ} 08^{\prime} 48^{\prime \prime N}, 14^{\circ} 23^{\prime} 06^{\prime \prime} \mathrm{E}, 5852$, Roztoky u Prahy, prameniště u Spáleného mlýna (u domu před Spáleným mlýnem) asi $10 \mathrm{~m}$ od Únětického potoka, a) 5.3 .2006$, b) $24.1 .2010 ; 34-50^{\circ} 05^{\prime} 39^{\prime \prime} \mathrm{N}, 1^{\circ} 19^{\prime} 24^{\prime \prime} \mathrm{E}$, 5951, Vokovice, Šárecký potok pod vodní nádrží Džbán, 14.5.2006; 35 - 5005'39"N, 14²19'02"E, 5951, Liboc, Šestákova studánka v Divoké Šárce asi $500 \mathrm{~m}$ západně od hráze vodní nádrže Džbán, 13.2.2010; 36 - 5005'46"N, $14^{\circ} 18^{\prime} 59 " E, 5951$, Liboc, Śárecký potok asi $700 \mathrm{~m}$ pod vodní nádrží Džbán, 13.2.2010; 37 - 5005'45"N, $14^{\circ} 18^{\prime} 01^{\prime \prime E}, 5951$, Ruzyně, pramenná stružka asi $100 \mathrm{~m}$ pod vodárničkou a $200 \mathrm{~m}$ od pramene (levostranný prrítok Šáreckého potoka vlévající se do něj u koupaliště v Divoké Šárce), 13.2.2010; 38 - 5005'52"N, 14¹8'29"E, 5951, Liboc, levostranný př́itok Šáreckého potoka u mostku cesty asi $1 \mathrm{~km}$ před ústím do Šáreckého potoka u koupaliště, 13.2.2010; 39 - 5005'56"N, 14²18'50"E, 5951, Liboc, studánka Šárecká Habrovka u levostranného přítoku Šáreckého potoka, 13.2.2010; 40 - 5005'58"N, 14¹9'05"E, 5951, Liboc, studánka Šárka u levostranného př́itoku Šáreckého potoka asi $200 \mathrm{~m}$ od ústí tohoto přítoku do Šáreckého potoka u koupaliště v Divoké Šárce, 13.2.2010; $41-50^{\circ} 05^{\prime} 58^{\prime \prime} \mathrm{N}, 1^{\circ} 19^{\prime} 06^{\prime \prime} \mathrm{E}, 5951$, Liboc, prameniště u cesty u levostranného prítoku Šáreckého potoka asi $150 \mathrm{~m}$ od ústí tohoto přítoku do Š́reckého potoka u koupaliště v Divoké Šárce, 13.2.2010; 42 - 5005'58"N, 14¹9'06"E, 5951, Liboc, levostranný př́tok Šáreckého potoka asi 150 $\mathrm{m}$ před ústím do Šáreckého potoka u koupaliště v Divoké Š́rce, 13.2.2010; 43 - 5006'05"N, 14²19'26"E, 5851, Liboc, Šárecký potok asi $2 \mathrm{~km}$ pod vodní nádrží Džbán, 13.2.2010; 44 - 5006'25"N, 14²0'25"E, 5852, Vokovice, pramenné stružky pod studánkou Primátorka nad nivou Šáreckého potka $1 \mathrm{~km}$ severně od východního okraje vodní nádrže Džbán, 13.2.2010; 45 - 5006'24"N, 14²0'36"E, 5852, Vokovice, prameniště v nivě Šáreckého potoka asi 200 m západně od studánky Roztočilka, 13.2.2010; 46 - 5006'21"N, 14²0'49"E, 5852, Vokovice, studánka Roztočilka v nivě Šáreckého potoka asi $500 \mathrm{~m}$ západně od PP Jenerálka, 13.2.2010; 47 - 5006'17"N, 14²0'59"E, 5852 , Dejvice, silnější pramen pod cestou asi $50 \mathrm{~m}$ západně od PP Jenerálka, 13.2.2010;48 - 5006'08"N, $14^{\circ} 21^{\prime} 15^{\prime} \mathrm{E}, 5852$, Vokovice, drobná vodní plocha protékaná Kruteckým potokem u jeho pramene v ulici Na Krutci, 9.1.2010; $49-50^{\circ} 06^{\prime} 15^{\prime \prime} \mathrm{N}, 1^{\circ} 21^{\prime} 01^{\prime \prime} \mathrm{E}, 5852$, Vokovi- ce, drobný prrítok u ústí do Kruteckého potoka asi $200 \mathrm{~m}$ od ústí Kruteckého potoka do Š́reckého potoka, 9.1.2010; 50 - 5006'15"N, 142 $21^{\prime} 02^{\prime \prime E}, 5852$, Vokovice, drobné prameniště u ústí přítoku do Kruteckého potoka asi $200 \mathrm{~m}$ od ústí Kruteckého potoka do Šáreckého potoka, 9.1.2010; 51 - 5006'19"N, 1421'03"E, 5852, Vokovice, Krutecký potok před ústím do Šreckého potoka, 9.1.2010; 52 - 5006'39"N, 14²0'59"E, 5852, Nebušice, Nebušický potok asi $450 \mathrm{~m}$ pod vodní nádrží, 9.1.2010; $53-50^{\circ} 06^{\prime} 33^{\prime \prime} \mathrm{N}, 14^{\circ} 21^{\prime} 06^{\prime \prime E}, 5852$, Nebušice, pramen Markéta za domem pod svahem v nivě Nebušického poto$\mathrm{ka}, 9.1 .2010 ; 54-50^{\circ} 06^{\prime} 32^{\prime \prime} \mathrm{N}, 1^{\circ} 21^{\prime} 08^{\prime \prime} \mathrm{E}, 5852$, Nebušice, pramenná stružka tekoucí od pramene Markéta v ul. Pod Habrovkou, 9.1.2010; 55 - 5006'27"N, 14²1'17"E, 5852, Nebušice, Nebušický potok asi $300 \mathrm{~m}$ před ústím do Šreckého potoka, 9.1.2010; 56 - 5006'25"N, 14²21'22"E, 5852, Nebušice, Nebušický potok asi $100 \mathrm{~m}$ před ústím do Šáreckého potoka, 14.2.2010;57 - 5006'23"N, $14^{\circ} 21^{\prime} 35^{\prime \prime E}, 5852$, Dejvice, prameniště na pravém břehu Šreckého potoka před mostem silnice v ul. K Dubovému Mlýnu, 14.2.2010; 58 - 5006'19"N, 14²1'36"E, 5852, Dejvice, prameniště a pramenná stružka nad olšinou naproti ul. K Dubovému Mlýnu, 14.2.2010; 59 - 5006'20"N, $14^{\circ} 21^{\prime} 37^{\prime \prime E}, 5852$, Dejvice, prameniště protékané pramennou stružkou v olšině naproti ul. K Dubovému Mlýnu, 14.2.2010; 60 - 5006'44"N, 1422'26"E, 5852, Dejvice, Śárecký potok asi $3 \mathrm{~km}$ před ústím do Vltavy, 12.1.2003; $61-50^{\circ} 07^{\prime} 22^{\prime \prime N}, 1^{\circ} 23^{\prime} 21^{\prime \prime E}, 5852$, Sedlec, Śárecký potok asi 400-500 m před ústím do Vltavy, 12.1.2003; 62 - 5007'34"N, 14²2'09"E, 5852, Lysolaje, Lysolajský potok pod požární nádrží asi 300 m pod Zázračnou studánkou, 4.3.2006; $63-50^{\circ} 07^{\prime} 30^{\prime \prime} \mathrm{N}, 1^{\circ} 22^{\prime} 33^{\prime \prime} \mathrm{E}, 5852$, Lysolaje, Lysolajský potok asi $1 \mathrm{~km}$ nad ústím do Šáreckého potoka, 4.3.2006.

\section{Výsledky a diskuse}

V letech 2003, 2006 a 2010 bylo na severozápadním okraji Prahy prozkoumáno celkem 63 lokalit odpovídajících svým charakterem možnému výskytu praménky Bythinella austriaca. Praménka byla zjištěna na celkem 11 lokalitách v okolí Středokluk, Statenic, v nivě potoka mezi Přední Kopaninou a Únětickým potokem, v nivě Únětického potoka u Spáleného mlýna a v nivě Nebušického potoka. $\mathrm{V}$ těchto oblastech byla praménka nalezena nejen ve vlastních pramenech, ale také v pramenných stružkách a v několika případech i v menších potocích. Početné populace byly zjištěny pouze ve vlastních pramenech. Zjištěný počet lokalit s pozitivním výskytem praménky je relativně nízký a to i přesto, že řada lokalit vizuálně odpovídala lokalitám $\mathrm{s}$ jejím výskytem. $\mathrm{V}$ některých prameništích docházelo $\mathrm{i}$ k usazování pěnovce a lokality připomínaly prameniště např. v Bílých Karpatech. Pro lepší srovnání by bylo nutné znát i další, především fyzikálně-chemické charakteristiky jednotlivých lokalit, či znalosti jejich historického vývoje. Bez těchto informací nelze blíže vysvětlit skutečnost proč se na některých stanovištích praménka vyskytuje a na některých obdobného charakteru a často v bezprostřední blízkosti nikoliv. Významný je však i samotný fakt, že praménka byla nalezena pouze na malé části potenciálně vhodných lokalit ve zkoumané oblasti a není zde obecně 
Tabulka 1. Přehled vodních měkkýšů podle lokalit. Vysvětlivky: odhad hustoty populace na $1 \mathrm{~m}^{2}$ plochy obývané uvedeným druhem $(\mathrm{O}-$ ojediněle, méně než 1 jedinec na $1 \mathrm{~m}^{2} ; \mathrm{R}$ - roztroušeně, 1-20 jedinců na $1 \mathrm{~m}^{2} ; \mathrm{H}$ - hojně, 20-100 jedinců na $1 \mathrm{~m}^{2} ; \mathrm{VH}$ - velmi hojně, více než 100 jedinců na $1 \mathrm{~m}^{2}$ ).

Table 1. List of aquatic molluscs according to localities. Explanations: estimation of population density ( $\mathrm{O}$ - solitary occurrence, less than 1 specimen per 1 square meter; $\mathrm{R}$ - scattered occurrence, 1-20 specimens per 1 square meter; $\mathrm{H}$ - abundant occurrence, 20-100 specimens per 1 square meter; VH - very abundant occurrence, over 100 specimens per 1 square meter).

\begin{tabular}{|c|c|c|c|c|c|c|c|c|c|c|c|c|c|c|c|c|c|}
\hline ले & & $\simeq$ & & & & & & & & & & & & & $\simeq$ & $\simeq$ & $m$ \\
\hline ల్లు & & & & & & & & & & & & & & & & 0 & - \\
\hline లె & & & & & & & & & & & & & & & $I$ & & - \\
\hline $\bar{m}$ & & & & & & & & & & & & & & & & $\simeq$ & - \\
\hline קి & & & & & & & & & & & & & & & 0 & 0 & N \\
\hline নे & & & & & & & & & & & & & & & $\simeq$ & & - \\
\hline 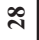 & & & & & & & & & & & & & & & 0 & & - \\
\hline$\lesssim$ & & & 0 & & 0 & & 0 & & & & & & & & & $\simeq$ & $\nabla$ \\
\hline$\stackrel{\sim}{\sim}$ & & & & & 0 & 0 & 0 & & & & 0 & & & & & 0 & in \\
\hline$\stackrel{2}{N}$ & & $I$ & & & 0 & & & & & & & & & & 0 & $\simeq$ & $\nabla$ \\
\hline ন & & $\simeq$ & & & & & & & & & & & & & 0 & $\simeq$ & $m$ \\
\hline$\approx$ & & & & & 0 & & $\simeq$ & & & & & & & & & $\simeq$ & $m$ \\
\hline$\approx$ & \pm & 0 & & & & & 0 & & & & & & & & & $\simeq$ & $\nabla$ \\
\hline $\bar{\sim}$ & $\Psi$ & 0 & & & & & 0 & & & & & & & & 0 & $\simeq$ & in \\
\hline 로 & I & 0 & & & & & & & & & & & & & & $\simeq$ & $m$ \\
\hline 2 & & 0 & & & & & & & & & & & & & 0 & & N \\
\hline$\infty$ & $\simeq$ & & & & & & & & & & & & & & & 0 & N \\
\hline$=$ & & & & & & & $\simeq$ & & & & & & & & & & - \\
\hline 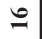 & & & & & & & & & & & & & & & 0 & 0 & N \\
\hline 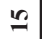 & & & & & & & & & & & & & & & & 0 & - \\
\hline \pm & & & & & & & & & & & & 0 & & & 0 & 0 & $m$ \\
\hline$m$ & & & & & & & & & & & & & & & $\simeq$ & 0 & N \\
\hline$\simeq$ & & & & & 0 & & & & & & & & & $I$ & & 0 & $\nabla$ \\
\hline$=$ & & & & & 0 & & & & & & & & & & 0 & $\simeq$ & $m$ \\
\hline$\Theta$ & & & & & & & & & & & & & & & & 0 & - \\
\hline$a$ & & & & & & & & & & & & & & & & 0 & - \\
\hline$\infty$ & & & & & & & & & & & & & & & & $\simeq$ & - \\
\hline$r$ & & & & & $\simeq$ & & 0 & & & & & & & & 0 & & $m$ \\
\hline 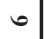 & & & & & & & 0 & & & & & & & & 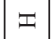 & & $N$ \\
\hline in & & & & & & & 0 & & & & & & 0 & $\simeq$ & & 0 & $\nabla$ \\
\hline$\nabla$ & & & 0 & & 0 & & 0 & & & & 0 & & $\simeq$ & 0 & & 0 & $r$ \\
\hline$m$ & & $I$ & & & & & & & & & & & & & & 0 & N \\
\hline$N$ & & & & & & & 0 & & & & & & & & & $\simeq$ & N \\
\hline- & & & & & & & $I$ & & & & & & & & & & - \\
\hline 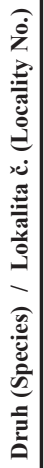 & 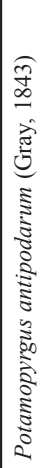 & 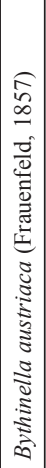 & 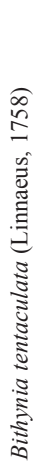 & 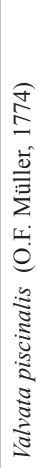 & 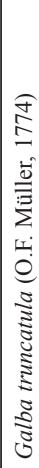 & 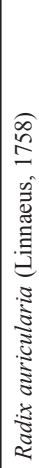 & 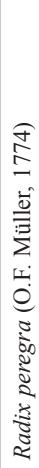 & 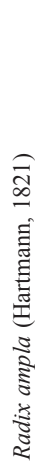 & 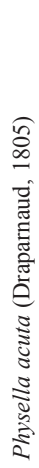 & 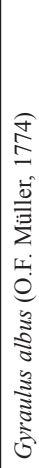 & 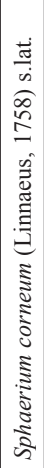 & 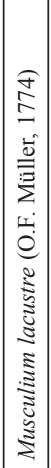 & 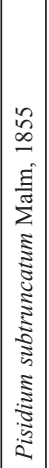 & 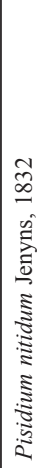 & 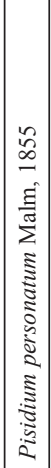 & 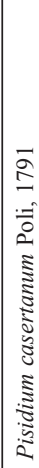 & 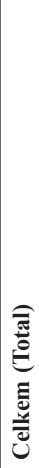 \\
\hline
\end{tabular}

\begin{tabular}{|c|c|c|c|c|c|c|c|c|c|c|c|c|c|c|c|c|c|}
\hline$\omega$ & $\simeq$ & $=$ & 0 & $\nabla$ & 2 & $\nabla$ & $\stackrel{\infty}{=}$ & - & $r$ & $N$ & $\infty$ & $N$ & $\nabla$ & $\nabla$ & $\ddot{x}$ & in & \\
\hline 3 & & & & & & & 0 & & & & & & & & & 0 & 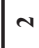 \\
\hline$\widetilde{\sigma}$ & & & & & & & $\simeq$ & & & & & & & & & & - \\
\hline 5 & 0 & & 0 & & & & 0 & & & & 0 & & $\simeq$ & & & 0 & 0 \\
\hline 8 & $\simeq$ & & & 0 & & & & & & & & & & & & $\simeq$ & 6 \\
\hline in & $\simeq$ & & & & & & & & & & & & & & & $\simeq$ & N \\
\hline in & $\simeq$ & & & & & & & & 0 & & & & & & & $\stackrel{F}{>}$ & 4 \\
\hline in & \pm & & & & & & & & & & & & & & 0 & \pm & $m$ \\
\hline in & \pm & & & & 0 & & & & 0 & & & & & & & $F$ & r \\
\hline in & 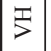 & 0 & & & & & & & $\simeq$ & & & & & & & \pm & r \\
\hline 呙 & \pm & 0 & & & & & & & & & & & & & & \pm & $m$ \\
\hline की & & $\stackrel{T}{>}$ & & & & & & & & & & & & & & & - \\
\hline$\tilde{n}$ & & & & & & & & & $\simeq$ & & & & & & & 0 & N \\
\hline $\bar{n}$ & & & & & 0 & & & & & & & & & & & 0 & N \\
\hline in & & & & & 0 & & & & & & & & & & & \pm & 4 \\
\hline$\hat{q}$ & & & & & 0 & & & & & & & & & & & 0 & N \\
\hline$\stackrel{\infty}{+}$ & & & & & 0 & & $\simeq$ & & & & & & & & & & N \\
\hline$f$ & & & & & & & & & & & & & & & & \pm & - \\
\hline 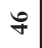 & & & & & & & & & & & & & & & & 0 & - \\
\hline 18 & & & & & & & & & & & & & & & 0 & $\simeq$ & 4 \\
\hline$\exists$ & & & & & & & & & & & & & & & 0 & & - \\
\hline$\%$ & & & 0 & 0 & & 0 & & & 0 & 0 & & & & & & $\simeq$ & 0 \\
\hline F & & & & & & & & & & & & & & & 0 & $\simeq$ & N \\
\hline$F$ & & & & & & & & & & & & & & & 0 & $\simeq$ & N \\
\hline F & & & & & & & & & & & & & & & 0 & 0 & 4 \\
\hline ले & & & & & & & & & & & & & & & 0 & 0 & N \\
\hline$\stackrel{\infty}{\infty}$ & & & & & & & & & & & & & & & $\simeq$ & \pm & N \\
\hline$\hat{m}$ & & & & & & & & & & & & & & & 0 & 0 & N \\
\hline ల & & & $\simeq$ & $\simeq$ & & 0 & 0 & & $\simeq$ & 0 & & & & & & 0 & r \\
\hline$\Leftrightarrow$ & & & & & & & & & & & & & & & 0 & & - \\
\hline $\overrightarrow{~ m}$ & & & $I$ & \pm & & 0 & 0 & 0 & 0 & & & $\simeq$ & 0 & 0 & & $\simeq$ & 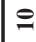 \\
\hline 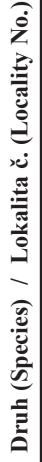 & 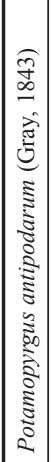 & 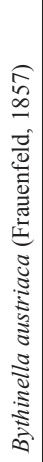 & 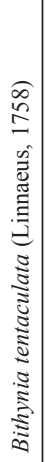 & 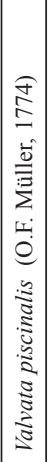 & 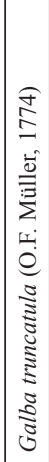 & 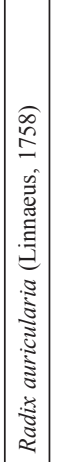 & 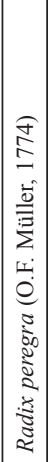 & 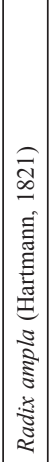 & 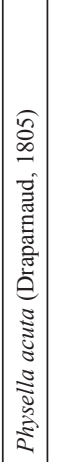 & 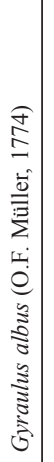 & 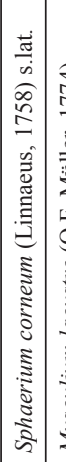 & 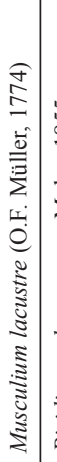 & 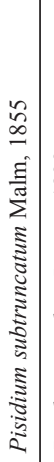 & 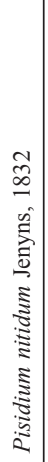 & 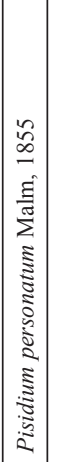 & 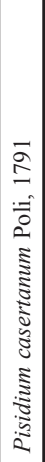 & 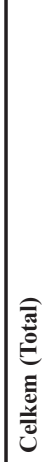 \\
\hline
\end{tabular}


rozšířena, jak tomu bývá v jiných oblastech jejího výskytu v ČR např. v Bílých Karpatech (BERAn \& HorsáK 2002). Pouze na jediné lokalitě se tento druh vyskytoval bez př́itomnosti dalších vodních měkkýšů. Na zbylých 10 lokalitách byl zjištěn s dalšími 1-4 druhy (blíže viz Tab. 1). Nejčastějším druhem, se kterým se praménka vyskytovala, byla hrachovka Pisidium casertanum a překvapivě také zavlečený předožábrý plž písečník novozélandský (Potamopyrgus antipodarum). Jeho výskyt v prameništích a pramenných stružkách a navíc společně s praménkou je vcelku překvapivý a v našich podmínkách nebyl prozatím publikován. V několika př́ípadech se s praménkou vyskytovaly také uchatka Radix peregra a hrachovka Pisidium personatum a v jediném př́padě i bahnatka Galba truncatula a zavlečená levatka Physella acuta. S výjimkou obou zmíněných zavlečených druhů se jedná o běžné a pro prameniště, pramenné stružky a drobné vodní toky typické vodní měkkýše.

Ve srovnání s předchozími nálezy Petrboka (1938a, 1939a, 1939b) a LožKA $(1945,1953)$ se podařilo potvrdit výskyt ve většině oblastí jimi uváděných. S ohledem na neprŕliš přesnou lokalizaci a také rozsáhlé změny v krajině za uplynulá desetiletí však nelze s jistotou potvrdit, že se jedná o totožné lokality a také nelze porovnat případnou početnost populací na jednotlivých lokalitách, nebot' z minulosti chybí kvantitativní data. V případě údajů J. Petrbo- ka odpovídá s jistotou lokalita ve Středoklukách (PETRBOK 1939a) autorově lokalitě č. 3. Nebylo možné identifikovat lokalitu „Prameny pod Tuchoměřicemi“ (РетRвок 1939b) a není jisté zda se skutečně jedná o lokality východně od Tuchoměřic mezi Přední Kopaninou a Únětickým potokem (lok. č. 19-22 a 24). Obdobná je situace u lokality „Pramen při horním konci Statenic“ (Petrbok 1938a), kde nelze potvrdit její identitu s lokalitou č. 25 . V př́padě údajů LožKA (1953) se podařilo potvrdit výskyt v nivě Nebušického potoka (lok. č. 53-55), zatímco průzkum nivy vlastního Šáreckého potoka, kde byl výskyt rovněž udáván (LožEK 1945), zůstal bez pozitivního výsledku. Výskyt uváděný v nedávné minulosti od Spáleného mlýna v nivě Únětického potoka (HofFMAnN \& PoKORNÝ 1997) se podařilo současnými průzkumy potvrdit také.

S ohledem na počet prozkoumaných lokalit je však nutné konstatovat, že situace tohoto předožábrého plže v okolí Prahy není prríliš optimistická, nebot' byl zjištěn pouze na malém počtu lokalit a to i přes skutečnost, že bylo snahou podchytit ve zkoumané oblasti většinu potenciálně vhodných stanovišt'. Některé lokality jsou navíc izolované jak je patrné z Obr. 2. Na řadě lokalit se vyskytují pouze slabé populace, na některých lokalitách se může jednat pouze o jedince splavené $z$ pramenišs' a většina lokalit je také snadno ovlivnitelná lidskou činností. Konkrétně v Tichém údolí se jedná o izolované drobné prameniště a pramen-

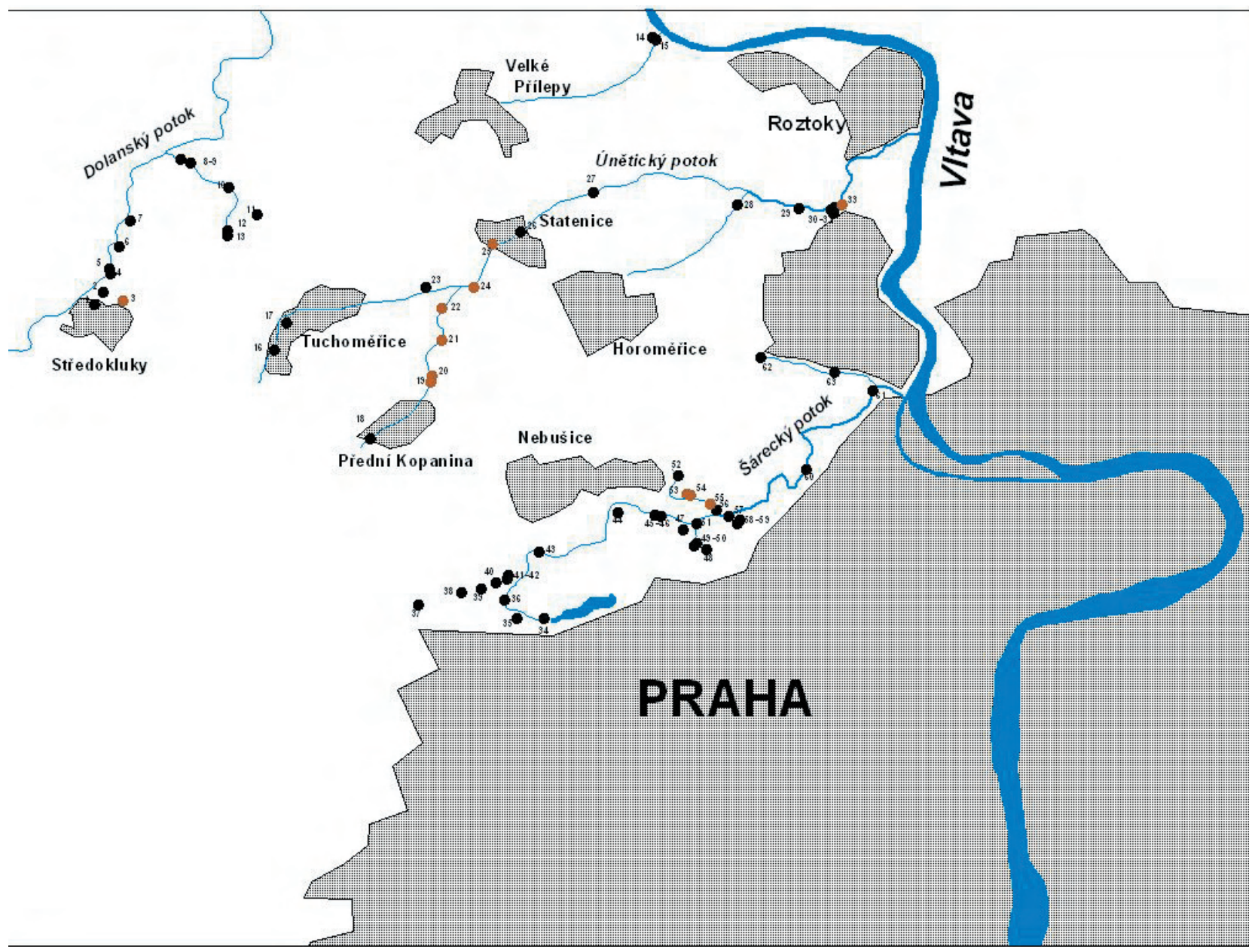

Obr. 2. Mapa zkoumaných lokalit. Vysvětlivky: hnědý kroužek - lokality s výskytem praménky Bythinella austriaca, černý kroužek - lokality bez výskytu praménky Bythinella austriaca.

Fig. 2. Map of localities under study. Explanations: brown circle - sites with occurrence of Bythinella austriaca, black circle - sites without occurrence of Bythinella austriaca. 
nou stružku. Praménka se však vyskytuje ve slabé populaci pouze bezprostředně po výtoku z pramene, ve vlastní stružce již nebyla $\mathrm{v}$ živém stavu nalezena. $\mathrm{V}$ případě $\mathrm{Ne}-$ bušického potoka došlo $\mathrm{v}$ uplynulých desetiletích $\mathrm{k}$ výrazným změnám. Jedno prameniště bylo zničeno v souvislosti s výstavbou, další dvě zanikla vybudováním vodní nádrže na pramenech Nebušického potoka a samotný Nebušický potok byl výstavbou vodní nádrže negativně ovlivněn. Zůstalo jediné prameniště zvané Markéta, které je tvořeno malým pramenem $\mathrm{v}$ betonových skružích (zde se praménka vyskytuje velmi početně) a pramennou stružkou, zčásti zatrubněnou a vedoucí skrz soukromou zahradu, ve které je výskyt praménky naproti zavlečenému druhu Potamopyrgus antipodarum méně početný. $\mathrm{V}$ př́padě výskytu $\mathrm{v}$ Nebušickém potoce se zřejmě jednalo pouze o splaveného jedince. Ve Statenicích se jedná o prameniště na soukromé zahradě, jehož existence může být ohrožena vlivem různých záměrů vlastníka (např. zatrubnění). Lepší situace je v nivě potoka mezi Přední Kopaninou a Únětickým potokem (lok. č. 19-22, 24). Zde se však praménka vyskytuje spíše ojediněle. Výjimkou je tak pouze početná populace v pramenné stružce v lesíku u Středokluk, kde zřejmě nedošlo za uplynulých 70 let k výraznějším změnám. Z tohoto výčtu je jednoznačně patrná intenzita antropogenních vlivů na prameniště v okolí Prahy a tím i na výskyt praménky rakouské. Je otázkou, zda se dokáže s těmito vlivy vyrovnat a přežít alespoň na těchto izolovaných lokalitách, nebot' pravděpodobnost jejího šíření je s ohledem na obývané biotopy prakticky minimální či spíše vyloučena. Pro další existenci tohoto druhu v okolí Prahy je nutná přinejmenším ochrana současných lokalit před technickými zásahy a úpravami jako jsou např. úpravy toků, zatrubnění prameništ' a dále také před znečištěním a to jak z bodových zdrojů (zástavba) tak i plošným. Její ochrana je o to více na místě s ohledem na skutečnost, že se jedná o velmi malou izolovanou oblast na okraji areálu tohoto druhu.

\section{Poděkování}

Průzkum v roce 2010 byl částečně podpořen Agenturou ochrany prírody a krajiny České republiky.

\section{Literatura}

Beran L., 2002: Vodní měkkýši České republiky - rozšíření a jeho změny, stanoviště, šíření, ohrožení a ochrana, červený seznam [Aquatic molluscs of the Czech Republic - distribution and its changes, habitats, dispersal, threat and protection, Red List]. - Sborník přírodovědného klubu v Uh. Hradišti, Supplementum 10, 258 pp.

BerAn L. \& Horsák M., 2002: Vodní měkkýši Chráněné krajinné oblasti Bílé Karpaty (Česká republika). [Aquatic molluscs of the Bílé Karpaty Protected Landscape Area (Czech Republic)]. - Sborník prrírodovědného klubu v Uh. Hradišti, 7: 63-76.

BerAn L., JuřičKová L. \& Horsák M., 2005: Mollusca (měkkýši), pp. 69-74. - In: FARKAČ J., KRÁL D. \& ŠKORPíK M. [eds.], Červený seznam ohrožených druhů České republiky. Bezobratlí. Red list of threatened species in the Czech Republic. Invertebrates. - Agentura ochrany prírody a krajiny ČR, Praha, $760 \mathrm{pp}$.

Buchar J., 1982: Způsob publikace lokalit živočichů z území Československa. - Věst. Čs. Společ. Zool., 46: 317-318.

GLÖER P., 2002: Süsswassergastropoden Nord- und Mitteleuropas. - ConchBooks, Hackenheim, 327 pp.

Hoffmann A. \& Pokorný J., 1997: Praménka rakouská opět v Praze. - Živa, 45(2): 77.

JuŘičKovÁ L., Horsák M., Beran L. \& Dvořák L., 2008: Check-list of the molluscs (Mollusca) of the Czech Republic. - http:// www.mollusca.sav.sk/malacology/checklist.htm, last update 26-August-2008

LožEK V., 1945: Praménka Bythinella austriaca Frauenfeld. - Věda př́rodní, 23(8): 243.

LožEK V., 1953: Nový nález praménky Bythinella austriaca Frfld. v chráněné šárecké oblasti. - Ochrana př́rody, 8(4): 92-93.

Mikvas K., 1963: Měkkýší zvířena Mladoboleslavska. - Muzeum v Mladé Boleslavi 1962, zpráva o činnosti, 3: 4 pp.

Petriok J., 1938a: Bythinella austriaca Frfld u Prahy. - Př́ŕroda, 31(5): 163-164.

PетRвок J., 1938b: I. Ulitnatí měkkýši čeští Národního musea v Praze. - Časopis Národního muzea, Oddělení př́rodovědné, 112: $107-108$.

Ретввок J., 1939a: Středokluky pátým novým nalezištěm praménky: Bythinella austriaca Frfld v Čechách. - Příroda, 32(6): 210.

Ретввок J., 1939b: Tuchoměřice šestým novým nalezištěm praménky Bythinella austriaca Frfld v Čechách. - Př́roda, 32(7): 242.

Pruner L. \& Míka P., 1996: Seznam obcí a jejich částí v České republice s čísly mapových polí pro sít’ové mapování fauny [List of settlements in the Czech Republic with associated map field codes for faunistic grid mapping system]. - Klapalekiana, 32, Suppl.: 1-175. 